\title{
REDUCTION IN ADVERSE ENVIRONMENTAL IMPACTS ASSOCIATED WITH THE OPERATION OF COMBINE HARVESTERS DURING THE HARVESTING OF WINTER OILSEED RAPE
}

\author{
Liudvikas ŠPOKAS $^{1}$, Dainius STEPONAVIČIUS ${ }^{1}$, Gediminas ŽEBRAUSKAS ${ }^{1}$, \\ Aušra ČIPLIENE $\dot{2}^{*}$, Laimis BAUŠA ${ }^{1}$ \\ ${ }^{1}$ Institute of Agricultural Engineering and Safety, Vytautas Magnus University, Studentu g. 15A, \\ LT-53362, Akademija, Kaunas district, Lithuania \\ ${ }^{2}$ Institute of Energy and Biotechnology Engineering, Vytautas Magnus University, Studentu g. 15A, \\ LT-53362, Akademija, Kaunas district, Lithuania
}

Received 27 June 2018; accepted 21 December 2018

\begin{abstract}
When harvesting winter oilseed rape (WOSR), leaving higher ( $\sim .3-0.4 \mathrm{~m})$ crop stubble is an effective method of reducing fuel consumption and contaminant emissions of a combine harvester equipped with the tangential threshing apparatus and straw walkers. At a speed of $4 \mathrm{~km} \mathrm{~h}^{-1}$, when the stubble height of WOSR was increased from 0.2 to $0.4 \mathrm{~m}$, the mass of material other than grain (MOG) fed to the harvester was reduced by $7 \mathrm{t} \mathrm{h}^{-1}$, resulting in a reduction of $6.2 \mathrm{l} \mathrm{h}^{-1}$ in fuel consumption, $5.7 \mathrm{~kg} \mathrm{~h}^{-1}$ in carbon equivalent (CE), and $16.3 \mathrm{~kg} \mathrm{~h}^{-1}$ in $\mathrm{CO}_{2}$ emissions. A more accurate estimate of harvester performance is the fuel consumption per ton of threshed seeds. On increasing the MOG mass feed rate to $15.6 \mathrm{t} \mathrm{h}^{-1}$, the fuel consumption per ton of threshed rapeseeds decreased to $3.33 \mathrm{lt}^{-1}$, CE reached $40.2 \mathrm{~kg} \mathrm{~h}^{-1}$ or $3.0 \mathrm{~kg} \mathrm{t}^{-1}$, and $\mathrm{CO}_{2}$ emissions reached $121.3 \mathrm{~kg} \mathrm{~h}^{-1}$ or $9.2 \mathrm{~kg} \mathrm{t}^{-1}$ of threshed rapeseed. When optimizing the automatic speed control system of the combine harvester, the MOG mass feed rate, the permissible limit of seed losses, and fuel consumption per ton of threshed seeds must be considered.
\end{abstract}

Keywords: combine harvester, fuel consumption, carbon dioxide, carbon equivalence, grain losses.

\section{Introduction}

Oilseed rape (Brassica napus L.) is among the most important oilseeds in the world, with a potentially high value as an edible oil and biofuel feedstock (Thiyam, Kuhlmann, Stöckmann, \& Schwarz, 2004). Rapeseed cake is used for compounding feeding stuffs (Jeong et al., 2014), and stems are used in the production of solid fuel (Chico-Santamarta, Godwin, Chaney, White, \& Humphries, 2013). However, during harvest, oilseed rape stems are first chopped using a combine harvester's straw chopper, then spread on the stubble, and finally incorporated into the soil (Jensen, Mueller, Magid, \& Nielsen, 1997). Moreover, oilseed rape blossoms are used by bees used to produce honey (Teper, Skubida, Semkiw, \& Skowronek, 2013). In Europe, oilseed rape is cultivated on approximately 6.5 million ha land and the total yield reaches 22 million ton (United States Department of Agriculture [USDA], 2018). The largest areas are located in European countries, such as Germany, Poland, and France. Winter oilseed rape (WOSR) is more prevalent and generates higher yields than spring oilseed rape (Rathke, Behrens, \& Diepenbrock, 2006; Zając, Klimek-Kopyra, Oleksy, Lorenc-Kozik, \& Ratajczak, 2016), but an increase in their area is prevented by sudden changes in ambient air temperatures during winter (Assefa et al., 2018). They (WOSR) are typical to the Baltic states because it is a region with a more humid climate. WOSR is harvested in the last 10 days of July, and spring oilseed rape is harvested at the end of August when the average moisture content of seeds is $\sim 12 \%$ (Špokas, Velička, Marcinkevičienè, \& Domeika, 2004).

Seed losses can be considered as a negative environmental factor in the cultivation of oilseed rape (PeltonenSainio, Pahkala, Mikkola, \& Jauhiainen, 2014). They may be caused by spontaneous opening of mature oilseed rapeseed pods and by seeds falling on the soil before the

${ }^{*}$ Corresponding author. E-mail: ausra.cipliene@asu.lt 
harvesting process (Bennett, Jeremy, \& Wagstaff, 2011). Different seed pods, inter alia, ripen on the same plant at different times. Seed pods a top the plant are the first to ripen, and when waiting for lower seed pods to ripen, the top ones open and seeds fall out of them on the soil (Špokas et al., 2004). Natural seed losses may reach 2\% (Price, Hobson, Neale, \& Bruce, 1996), and in the year when the weather conditions are adverse 1 month before harvesting or when harvesting is longer, they may reach approximately 30\% (Kosteckas et al., 2009; Špokas et al., 2004). Rapeseeds that fall on the soil surface are incorporated into the soil after harvesting when stubble is breaking, and they are viable for 3 years (Peltonen-Sainio et al., 2014) up to 10 years (Lutman, Freeman, \& Pekrun, 2003). Thus, oilseed rape plants grown from these seeds become unnecessary in the same field the following year (Haile, Holzapfel, \& Shirtliffe, 2014) because oilseed rape itself becomes a weed, the eradication of which requires herbicides, leading to a negative environmental impact (glyphosate is predominantly used at approximately $2 \mathrm{l} \mathrm{ha}^{-1}$ of the active ingredient). At the same time, working hours and fuel consumption increase, thereby increasing the cost of seed production (Peltonen-Sainio et al., 2014). The amount of natural rapeseed losses depends mainly on the pod resistance to shattering, which in turn depends on the genetic features of the oilseed rape variety, weather conditions, cultivation agrotechnics (Assefa et al., 2018; Rathke et al., 2006), and the use of additional preparations known as pod sealants (Bauša, Steponavičius, Jotautienè, Kemzūraitè, \& Zaleckas, 2018; Haile et al., 2014).

Another part of rapeseed losses is faced during oilseed rape harvesting (Hobson \& Bruce, 2002). Most of these losses are incurred when the cutting parts of a combine harvester (reel and active separators/dividers) are in contact with the harvested oilseed rape plants (Pari et al., 2012). Rapeseed losses during yield processing may range from $2 \%$ to $5 \%$, and in a year when harvesting is prolonged due to adverse weather conditions, they range from $11 \%$ to $25 \%$ (Price et al., 1996). Based on a study by Gulden, Shirtliffe, and Thomas (2003), the average yield losses of $107 \mathrm{~kg} \mathrm{ha}^{-1}$ or $5.9 \%$ of the crop seed yield were observed. This amounted to seedbank additions of $\sim 3000$ viable seeds per square meter. The yield losses among the producers ranged from $3.3 \%$ to $9.9 \%$ or from 9 to 56 times the normal seeding rate of oilseed rape (Gulden et al., 2003). Rapeseed losses due to harvesting depend on the moisture content of rapeseeds and stems, material other than grain (MOG), combine harvester design, technological adjustment parameters, and qualification of a combine harvester operator (Miu, 2015). In addition, both natural rapeseed losses and the ones incurred during harvesting reduce the effectiveness of energy used to grow these plants (Peltonen-Sainio et al., 2014). In short, taking measures to reduce rapeseed losses would significantly contribute toward reducing the negative environmental impact.

Another negative environmental impact associated with the harvesting of oilseed rape crops with self-propelled combine harvesters is fuel consumption (Fríd, Dolan, Celjak, Filip, \& Bartos, 2017; Špokas \& Steponavičius, 2011). The power output of diesel engines of the most efficient combine harvesters reaches $300 \mathrm{~kW}$. Fossil fuels are non-renewable, and their combustion generates greenhouse gases (GHGs), e.g., $\mathrm{CO}_{2}$, which are inimical to the environment, constituting the main reason causing global warming (Olivier, Maenhout, \& Peters, 2012). A liter of diesel weighs $835 \mathrm{~g}$, with $86.2 \%$ of the fuel comprising carbon. To combust this carbon to $\mathrm{CO}_{2}, 1920 \mathrm{~g}$ of oxygen is needed. The sum is then $2640 \mathrm{~g}$ of $\mathrm{CO}_{2}$ per liter of combusted diesel in the engine (Oyediran \& Wufem, 2017). Koga, Tsuruta, Tsuji, and Nakano (2003) observed that from an environmental viewpoint, fuel savings through efficient utilization will have a commensurate positive effect on the reduction in $\mathrm{CO}_{2}$ emissions in crop production systems. Combined diesel engines use diesel fuel and emit combustion products to the environment predominantly consisting of $\mathrm{NO}_{\mathrm{X}}, \mathrm{NH}_{3}, \mathrm{CO}$, and $\mathrm{CO}_{2}$ gases. The 4 main pollutant emissions from diesel engines include $\mathrm{CO}$, hydrocarbon (HC), particulate matter (PM), and $\mathrm{NO}_{\mathrm{x}}$ (Juostas \& Janulevičius, 2014). The diesel engine of modern combine harvesters is a four-stroke engine with an electronically controlled fuel injection process. More specifically, the timing and duration of fuel injection are controlled by opening the associated solenoid valves. This allows for optimizing the generated power, while fuel consumption and exhaust emission are diminished (Miu, 2015). If the negative environmental effects of harmful exhaust gases are reduced in the latest combine harvesters by installing various systems, e.g., diesel oxidation catalyst to control $\mathrm{CO}$ and $\mathrm{HC}$ emissions, selective catalytic reduction to control $\mathrm{NO}_{\mathrm{X}}$, and clean-up catalyst (Reşitoğlu, Altinişik, \& Keskin, 2015), a significant reduction in $\mathrm{CO}_{2}$ emissions is possible only by reducing fuel consumption. Fuel consumption and exhaust gas emissions are crucial indicators for evaluating the environmental impact of combine harvesters (Tomita et al., 2013).

Kehayov, Vezirov, and Atanasov (2004) reported that leaving higher stubble when harvesting a crop with combine harvesters reduces fuel consumption. Considering the diameter, moisture content, and mass of oilseed rape stems are larger near the soil surface (Christen \& Friedt, 2011); then, when oilseed rape is not lodged, it may be cut leaving higher stubble. Then, a lower MOG mass would be fed to the combine harvester, the oilseed rape harvesting rate would increase, and fuel consumption would be reduced. However, the effect of the stubble height of oilseed rape on fuel consumption of combine harvesters and seed losses has not been studied and no relation between seed losses and fuel consumption has been established.

This study aims to provide justification for measures to reduce fuel consumption, $\mathrm{CO}_{2}$ emissions, and oilseed rapeseed losses during oilseed rape harvesting using combine harvesters. 


\section{Material and methods}

\subsection{Biometric indices of oilseed rape}

Before harvesting oilseed rape, the stems were divided into 5 plots of $0.25 \mathrm{~m}^{2}$ area each and placed in separate tight bags. The bags were transported to the laboratory of Aleksandras Stulginskis University, located $\sim 0.5 \mathrm{~km}$ from WOSR field. In the laboratory, on the same day seed pods were cut from each stem and counted. The average number of seeds was calculated, and the mass of 1000 seeds and the height of each stem were measured. Samples of oilseed rape stems, stubs, and seeds were taken to evaluate the moisture content. The samples were dried in an induction oven at $103^{\circ} \mathrm{C}$ for $24 \mathrm{~h}$ (under constant humidity) (ASAE, 1993). Biological rapeseed yield and stubble mass in all plants' stem mass were calculated. The mass and yield of the seeds were calculated at a moisture content of $9 \%$.

\subsection{Moisture and mass variation in stem lengths}

In the laboratory, stems of 5 oilseed rape samples were cut into 100-mm-long pieces. The length of the stems and pieces were measured with a special 2-m-long ruler (reading accuracy: $\pm 1 \mathrm{~mm}$ ). In total, 5 samples were taken to determine the moisture content. The moisture content of pieces of each stem length class and the share of their mass in the total stem mass were calculated.

\subsection{Fuel consumption}

The fuel consumption $\left(\mathrm{l} \mathrm{h}^{-1}\right)$ of combine harvester $\mathrm{A}$ (Table 1) was measured using the instrument AIC-888 Instructor (Automotive Information and Control Systems AG, Switzerland). Its inspection is compliant with EuroNorm $95 / 54 / C E$. The measurement data error was $\pm 1 \%$. The variation in instant fuel consumption $\left(\mathrm{l} \mathrm{h}^{-1}\right)$ of the combine harvester $\mathrm{B}$ engine was measured by a connected diagnostic computer. The average fuel consumption per ton of threshed seeds and per hectare of harvested oilseed rape was calculated during rape yield processing.

Scientists suggest that when assessing the environmental impact of fuel consumption for various agricultural operations, it is useful to link them with carbon consumption. Equivalent coefficients are used in the calculations for this purpose (Lal, 2004). In this study, fuel consumption during oilseed rape-harvesting operations was converted into carbon equivalent (CE). A principal advantage of expressing energy use in terms of carbon emission as $\mathrm{kg}$ CE lies in its direct relation to the rate of enrichment of atmospheric concentration of $\mathrm{CO}_{2}(\mathrm{Lal}, 2004)$. The estimated diesel values $(\mathrm{kg})$ were converted into $\mathrm{kg} \mathrm{CE}$ using the emission coefficient, and an average value (0.94) was used for simplification (Lal, 2004). Since the density of diesel is $0.832 \mathrm{~kg} \mathrm{l}^{-1}$, for conversion of 11 diesel into CE, a coefficient value of 0.915 is used.

Moreover, $\mathrm{CO}_{2}$ emissions were not measured in this study but were calculated based on fuel consumption.
To estimate the amount of $\mathrm{CO}_{2}$ emissions caused due to burning of fuel used in oilseed rape harvesting, a conversion coefficient of $2.63 \mathrm{~kg} \mathrm{l}^{-1}$ was used for diesel following the approach taken by Koga et al. (2003).

\subsection{Straw walker and cleaning shoe seed losses}

When harvesting oilseed rape, the width of the section of the spread chopped straw of the combine harvester (b) was determined. In total, 2 truncated cone-shaped containers with an area of $0.0213 \mathrm{~m}^{2}$ were placed under the combine harvester: one of them was placed next to the steering wheel, whereas the other was placed 1 $\mathrm{m}$ from it (Špokas \& Steponavičius, 2011). Rapeseeds that were collected in the containers were counted. The moisture content of the seeds was determined using a moisture meter (Pfeuffer HE lite; reading accuracy: $\pm 0.1 \%)$. The seed losses (\%) associated with the straw walker and cleaning shoe were calculated using the following equation:

$$
N=\frac{\beta a g b}{A_{g} L},
$$

where: $\beta$ is dimensionless conversion factor, estimating the area of cone-shaped seed loss containers and the average number of seeds per container $(\beta=0.047) ; a$ is the average number of seeds per container (pcs); $g$ represents the weight of 1000 seeds $(\mathrm{g})$; $L$ represents the width of the combine harvester's cutter bar $(\mathrm{m}) ; b$ represents the width of the section of spread chopped straw (m); and $A_{g}$ represents oilseed rapeseed yield $\left(\mathrm{t} \mathrm{ha}^{-1}\right)$.

\subsection{Combine harvesters}

WOSR was harvested using 2 combine harvesters with a tangential threshing apparatus and installed straw walkers (Table 1).

Table 1. Most important technical data of combine harvester

\begin{tabular}{|l|c|c|c|}
\hline \multirow{2}{*}{ Indices } & \multirow{2}{*}{$\begin{array}{c}\text { Measuring } \\
\text { units }\end{array}$} & \multicolumn{2}{|c|}{ Combine harvester } \\
\cline { 3 - 4 } & $\mathrm{m}$ & 6.0 & $\mathrm{~B}$ \\
\hline Header (cutter bar) width & $\mathrm{m}$ & 0.6 & 0.6 \\
\hline $\begin{array}{l}\text { Threshing cylinder } \\
\text { diameter }\end{array}$ & $\mathrm{m}$ & 1.7 & 1.7 \\
\hline Threshing cylinder length & $\mathrm{m}^{2}$ & 1.73 & 1.73 \\
\hline $\begin{array}{l}\text { Total separation area of } \\
\text { concaves }\end{array}$ & $\mathrm{m}^{2}$ & 5.8 & 5.8 \\
\hline $\begin{array}{l}\text { Total separation area of } \\
\text { sieves }\end{array}$ & 1 & 8100 & 11000 \\
\hline Grain tank capacity & $\mathrm{kW}$ & 203 & 330 \\
\hline Engine power & & & \\
\hline
\end{tabular}

Considering the combine harvesters design differences, technological parameters were established during the process of oilseed rape harvesting (Table 2). 
Table 2. Technological parameters of combine harvesters

\begin{tabular}{|c|c|c|c|c|c|}
\hline $\begin{array}{c}\text { Combine } \\
\text { harvester }\end{array}$ & $\begin{array}{c}\text { Threshing cylinder } \\
\text { rotation speed } \\
\left(n_{b}, \mathrm{rpm}\right)\end{array}$ & $\begin{array}{c}\text { Cleaning shoe fan rotation } \\
\text { speed }\left(n_{v}, \mathrm{rpm}\right)\end{array}$ & $\begin{array}{c}\text { Spacing between the } \\
\text { threshing cylinder and } \\
\text { the concave }(c, \mathrm{~mm})\end{array}$ & $\begin{array}{c}\text { Spacing between } \\
\text { the upper sieve } \\
\text { plates }(b, \mathrm{~mm})\end{array}$ & $\begin{array}{c}\text { Spacing between } \\
\text { the lower sieve } \\
\text { plates }\left(b_{1}, \mathrm{~mm}\right)\end{array}$ \\
\hline $\mathrm{A}$ & 500 & 880 & 25 & 7 & 3 \\
\hline $\mathrm{B}$ & 500 & 870 & 25 & 9 & 4 \\
\hline
\end{tabular}

Table 3. Weather conditions in July and August of 2012-2016 (Kaunas Meteorological Station)

\begin{tabular}{|c|l|c|c|c|c|}
\hline Year & Month & Air temperature $\left({ }^{\circ} \mathrm{C}\right)$ & Relative humidity $(\%)$ & Precipitation $(\mathrm{mm})$ & Number of rainy days $\left(\right.$ units $\left.{ }^{*}\right)$ \\
\hline \multirow{2}{*}{2012} & July & 19.4 & 79 & 110.4 & 15 \\
\cline { 2 - 6 } & August & 17.1 & 81 & 69.2 & 10 \\
\hline \multirow{2}{*}{2013} & July & 18.6 & 73 & 67.2 & 13 \\
\cline { 2 - 6 } & August & 18.1 & 73 & 70.7 & 10 \\
\hline \multirow{2}{*}{2014} & July & 20.6 & 66 & 711.3 & 14 \\
\cline { 2 - 6 } & August & 17.7 & 73 & 6.9 & 12 \\
\hline \multirow{2}{*}{2015} & July & 17.4 & 71 & 164.0 & 4 \\
\cline { 2 - 6 } & August & 20.2 & 58 & 115.0 & 14 \\
\hline \multirow{2}{*}{2016} & July & 18.0 & 81 & & 15 \\
\cline { 2 - 6 } & August & 16.9 & 81 & & 14 \\
\hline
\end{tabular}

Note: ${ }^{\star}$ Precipitation $>0.5 \mathrm{~mm}$.

\subsection{Weather conditions}

The beginning of the WOSR harvest time is predominantly influenced by the weather conditions in July (Table 3 ). The month of July of 2012-2016 had an average of 13 rainy days, and the month of August of the same time period had 11 rainy days, with more than $0.5 \mathrm{~mm}$ precipitation. The month of August of 2015 had the lowest precipitation $(6.9 \mathrm{~mm})$ during the last decade, while the month of August of 2016 had the highest precipitation $(164 \mathrm{~mm})$.

\subsection{Statistical analysis}

The experiments of rapeseed shattering were conducted with a total of 7 replicates, whereas others were conducted in triplicate. Data were analyzed with the statistical software Statistica 10.0, and a significance level of 0.05 was used as the criterion for significance testing.

\section{Results and discussion}

WOSR was studied during 2009-2016. In the laboratory, biometric parameters of oilseed rape were evaluated, along with variations in the moisture content and mass in the length of the stems. Fuel consumption was tracked during oilseed rape harvesting, and seed losses associated with straw separation and chaff cleaning were estimated to examine the relations among these parameters.

\subsection{Biometric indices of oilseed rape}

The crop density of the 3 different WOSR varieties differed, as reported in Table 4 . When oilseed rape was harvested, the stubble height was limited by the distance from the soil to the first branch and the degree of oilseed rape lodging.

\subsection{Stubble height and MOG mass of oilseed rape fed to the combine harvester}

In Germany, Reckleben and Vosshenrich (2008) reported the effects of wheat stubble height on combine harvester fuel consumption and found that by increasing stubble height from 0.1 to $0.2 \mathrm{~m}$, fuel consumption per hectare was reduced by $4 \mathrm{l}$. To the best of our knowledge, the effect of the stubble height of oilseed rape on the combine harvester's fuel consumption (per ton of threshed seeds) and performance indicators has not been studied. In this study, the seed moisture content at the time of harvesting WOSR Catalina was $9.2 \%$ and the moisture content in the total stem mass was $75.3 \%$. When harvesting oilseed rape, leaving a stubble height of $0.2-0.3 \mathrm{~m}$ is a common agricultural practice (Christen \& Friedt, 2011). If oilseed rape is not lodged or oilseed rape branches are not bent, the stubble height may reach $0.4 \mathrm{~m}$ (Špokas \& Steponavičius, 2011). The study results demonstrated that the stubble mass (height: $0.2 \mathrm{~m}$ ) was $39.2 \pm 2.6 \%$ of the total MOG mass (Figure 1). Stubble moisture content was $82.3 \pm 0.7 \%$, and the moisture content of the rest of the MOG mass was $71.9 \pm 1.8 \%$. When harvesting oilseed rape, if the stubble height is increased from 0.2 to $0.3 \mathrm{~m}$, the harvester will be fed an MOG mass that is $11.9 \pm 0.8$ percentage points less and contains 1.5 percentage points less moisture, which indicates that only $\sim 50 \%$ of the total mass of the plant stems would be fed to the threshing apparatus of the combine harvester.

Moreover, similar results were obtained when the effect of the stubble height of WOSR Sunday on the MOG mass fed to the harvester was determined. During the harvesting of the Sunday variety, the seed moisture content reached $17.25 \%$ and the stem moisture content reached $80.43 \%$. 


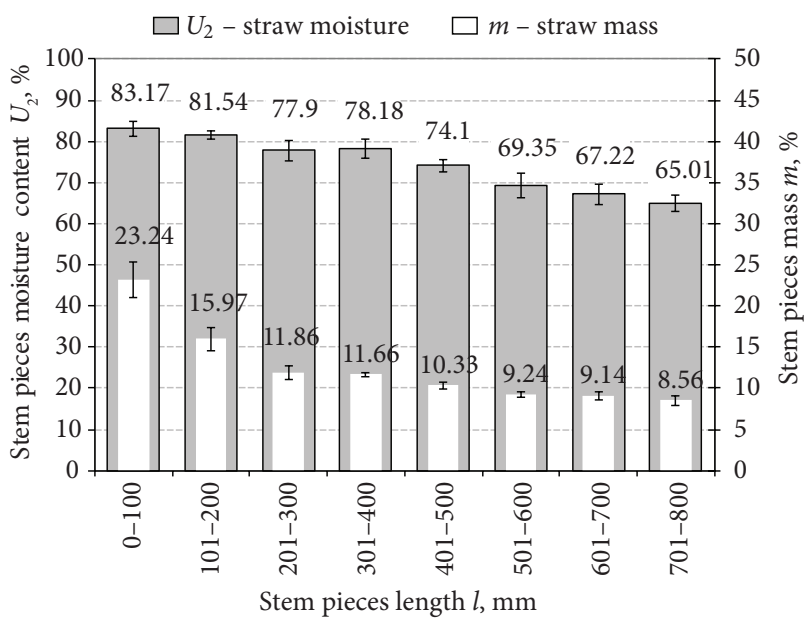

Figure 1. Change in mass $\left(m_{1}\right)$ and moisture content $\left(U_{2}\right)$ of separate 100-mm-long stem pieces of WOSR Catalina

The stubble with a height of $0.2 \mathrm{~m}$ was $47.30 \pm 1.59 \%$ of the total mass of the stems. When the stubble height is increased to $0.3 \mathrm{~m}$, the harvester would be fed the MOG mass that is lower by $13.60 \pm 0.61$ percentage points and contains 2.5 percentage points less moisture. The higher the moisture content of the harvested oilseed rape, the higher the share of the stubble (lower part of the plant stems) in the total MOG mass.

Having summarized the mass variations in the stem length $(0.45 \mathrm{~m})$ of various WOSR varieties in 2009-2012, a close relation was found between stubble height $(h ; \mathrm{m})$ and the share of its mass $(m ; \%)$ in the total MOG mass:

$$
\begin{gathered}
m=107.23 h^{2}-98.55 h+33.45 ; \\
R^{2}=0.97 \quad(0.05<h<0.45) .
\end{gathered}
$$

The moisture content decreases slowly in oilseed rape stem length. There is a linear dependence between the stubble height and its moisture content $U_{2}$.

$$
\begin{aligned}
& U_{2}=-17.97 h+85.13 ; \\
& R^{2}=0.99 .
\end{aligned}
$$

In short, when harvesting non-lodged oilseed rape, the optimum stubble height must be $0.3 \mathrm{~m}$, whereby its mass accounts for $>50 \%$ of the total mass of stems. Higher stubble height is often restricted by the distance between the soil surface and the first branches of oilseed rape stems containing seed pods because the harvester must cut the plant short enough to obtain these lowest hanging seeds.

\subsection{Fuel consumption}

Research on the environmental impact of oilseed rape harvesting is relatively sparse. Special analytical techniques are needed to determine seed losses, and a diagnostic computer is required to determine the harvester's hourly fuel consumption, with this value being dependent on the harvester's load (Fríd et al., 2017; Špokas \& Steponavičius, 2011). It changes significantly only when technological gears are switched on, while there is no oilseed rape being fed to the harvester (i.e., the harvester is operating without an actual harvesting load and without performing the oilseed rape operations, e.g., cutting and threshing; Table 5). During harvester operations, the crankshaft of the internal combustion diesel engine rotates at its maximum (1965 revolutions per minute). When the harvesters were not performing oilseed rape cutting and threshing, the hourly fuel consumption of combine harvester B was $4.30 \pm 0.59 \mathrm{l}$ higher than harvester A's consumption. This was due to the higher mass and engine power of harvester $B$ (Table 1). When the combine harvesters are stopped for technical inspection, it is necessary to switch off the technological gears and reduce the rotation of diesel engine crankshaft from 1965 to $1400 \mathrm{rpm}$. The engines of harvesters A and B consume 12.3 and $14.5 \mathrm{l} \mathrm{h}^{-1}$ less fuel, respectively. The conversion of fuel consumption into $\mathrm{CE}$ indicated that $\mathrm{CE}$ would be reduced by 13.3 and $11.3 \mathrm{~kg} \mathrm{~h}^{-1}$, corresponding to the reduction in $\mathrm{CO}_{2}$ emissions of 38.1 and $29.0 \mathrm{~kg} \mathrm{~h}^{-1}$, respectively. This supports the proposition that maintaining fuel efficiency decreases GHG emissions (Dyer \& Desjardins, 2003).

During harvesting, combine harvesters must often drive from one field to another at the end of crop rows without harvesting crops while in transit (Miu, 2015). At that time, technological gears are not always switched off and a reasonable driving speed is not maintained.

\begin{tabular}{|c|c|c|c|c|}
\hline \multirow{2}{*}{ Index } & \multirow{2}{*}{ Measurement unit } & \multicolumn{3}{|c|}{ WOSR variety } \\
\hline & & Catalina & Sunday & Visby \\
\hline Crop density & stems $\mathrm{m}^{-2}$ & $43.20 \pm 4.91$ & $45.3 \pm 2.8$ & $32.3 \pm 3.36$ \\
\hline Height of plants & $\mathrm{m}$ & $1.27 \pm 0.05$ & $1.24 \pm 0.05$ & $1.78 \pm 0.03$ \\
\hline $\begin{array}{l}\text { Distance from soil surface to the first branch } \\
\text { of the plant }\end{array}$ & $\mathrm{m}$ & $0.47 \pm 0.11$ & $0.41 \pm 0.07$ & $0.52 \pm 0.06$ \\
\hline Stubble $(0.25 \mathrm{~m})$ share in the total stem mass & $\%$ & $44.96 \pm 6.27$ & $56.15 \pm 2.14$ & $46.95 \pm 2.16$ \\
\hline Weight of 1000 seeds $(9 \%)^{*}$ & g & $3.70 \pm 0.13$ & $4.80 \pm 0.04$ & $4.37 \pm 0.06$ \\
\hline Biological yield $(9 \%)^{*}$ & $\mathrm{tha}^{-1}$ & $2.74 \pm 0.77$ & $5.25 \pm 0.44$ & $4.90 \pm 0.51$ \\
\hline
\end{tabular}
This study found that when combine harvester B drives over the stubble (its speed varied from 2 to $12 \mathrm{~km} \mathrm{~h}^{-1}$ ),

Table 4. Biometric indices of winter rape

* Seed moisture content. 
fuel consumption for rotating technological gears was $9.10 \mathrm{l} \mathrm{h}^{-1} \pm 0.73 \mathrm{l} \mathrm{h}^{-1}$ (Figure 2) or $8.3 \mathrm{~kg} \mathrm{~h}^{-1}$ of CE and almost $24 \mathrm{~kg} \mathrm{~h}^{-1}$ of $\mathrm{CO}_{2}$. Thus, to save fuel, the gears must be turned off while driving between fields. While more fuel is consumed when the combine harvester is driven at higher speeds without harvesting, fuel consumption is lower for equal distances. A reasonable driving speed over the stubble with a full grain tank of seeds is $10 \mathrm{~km} \mathrm{~h}^{-1}$, which may reach up to $15 \mathrm{~km} \mathrm{~h}^{-1}$ with an empty grain tank. When driving without harvesting, it is necessary to switch off the technological gears and reduce the engine speed from 1965 to $1400 \mathrm{rpm}$. As a result, the engine fuel consumption is further reduced by $6.71 \mathrm{~h}^{-1}$.

It is known that the performance quality indicators of the combine harvesters and the fuel consumption depend on the quantity and composition of mass supplied to the combine harvesters (Miu, 2015). The MOG mass of mature oilseed rape plants is 3 times larger than that of seeds. Studies have shown that moisture content in the stem length of mature oilseed rape varies between $20 \%$ and $70 \%$ depending on the variety and environmental conditions (Christen \& Friedt, 2011).

This study found that leaving higher stubble in the field is the most reasonable way to achieve reduction in the MOG mass feed rate and fuel consumption when the combine harvester maintains the same driving speed, resulting in a reduction in emissions. When combine harvester $B$ was driven at a speed of $4 \mathrm{~km} \mathrm{~h}^{-1}$, increasing the stubble height of WOSR Visby from 0.2 to $0.4 \mathrm{~m}$ (Figure 3), the combine harvester was fed by $7 \mathrm{t} \mathrm{h}^{-1}$ less MOG mass, resulting in an hourly fuel consumption lower by $6.21 \mathrm{~h}^{-1}$, which in turn resulted in $5.7 \mathrm{~kg} \mathrm{~h}^{-1}$ less CE and $16.3 \mathrm{~kg} \mathrm{~h}^{-1}$ less $\mathrm{CO}_{2}$. The study has shown that the reduction rate of fuel consumption depends not only on the straw mass fed to the harvester but also on its composition (e.g., the share of weeds in MOG mass).

The MOG mass fed to the combine harvester depends not only on the stubble height but also on the driving speed (Reckleben \& Vosshenrich, 2008). Due to the changing working conditions of harvested oilseed rape fields and the degree of oilseed rape lodging, modifying the combine harvester's driving speed is often necessary to ensure constant feeding of MOG mass and staying within the permissible $0.5 \%$ limit of seed losses associated with straw separation and chaff cleaning, performed by the straw walker and cleaning shoe. In practice, the driving speeds of combine harvesters are changed more often than the stubble height.

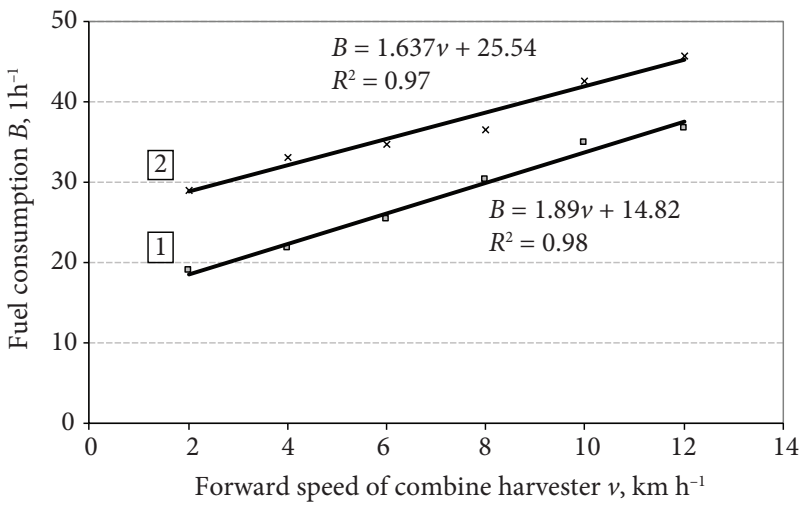

Figure 2. Effect of driving speed of combine harvester B over stubble on hourly fuel consumption when $n=1965 \mathrm{rpm}$. (1) indicates that technological gears are switched off, and (2) indicates that they are switched on

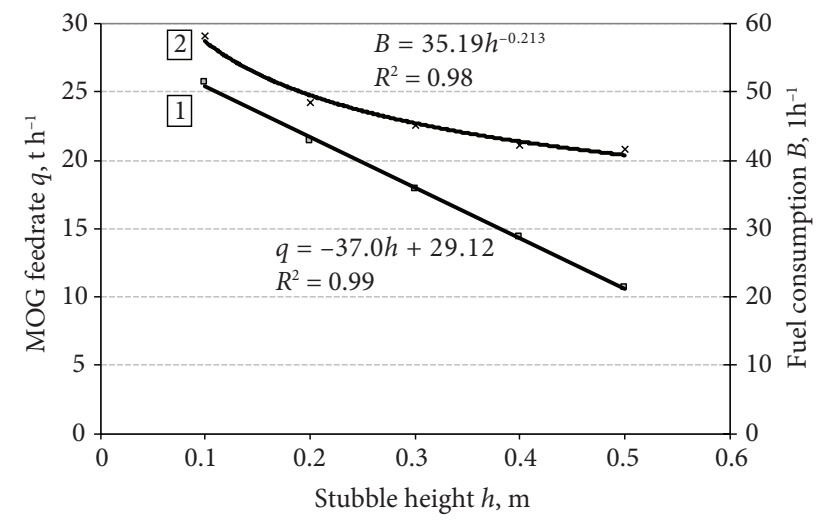

Figure 3. Effect of stubble height of WOSR Visby $(h)$ on the quantity of straw fed to combine harvester B $(q)$ and on the hourly fuel consumption $(B)$ when the biological straw yield $A_{1}=10.8 \mathrm{tha}^{-1}$, seed yield $A_{\mathrm{g}}=4.9 \mathrm{tha}^{-1}, U_{1}=8.7 \%$, and MOG $=68.8 \%$. (1) represents the MOG mass fed to the harvester $\left(q ; \mathrm{t} \mathrm{h}^{-1}\right)$, and (2) represents hourly fuel consumption $\left(B ; 1 \mathrm{~h}^{-1}\right)$

In most studies, the fuel consumption of a combine harvester is set in liters per hectare of the crops harvested (Fríd et al., 2017; Strakšas, Kučinskas, Šniauka, \& Vaiciukevičius, 2013). The fuel consumption per hectare of harvested oilseed rape was approximately $161 \mathrm{ha}^{-1}$ (Fríd et al., 2017). Carbon emissions were also calculated per hectare of the harvested crop, including $16.47 \mathrm{~kg} \mathrm{C} \mathrm{ha}^{-1}$ for harvesting wheat (West \& Marland, 2002), 14.5$15.0 \mathrm{~kg} \mathrm{CE} \mathrm{ha}{ }^{-1}$ for harvesting WOSR (Fríd et al., 2017), and $11.50 \mathrm{~kg} \mathrm{CE} \mathrm{ha}^{-1}$ for harvesting maize (Lal, 2004).

Table 5. Hourly fuel consumption of combine harvester engines without technological threshing process

\begin{tabular}{|c|c|c|c|c|c|}
\hline \multirow{2}{*}{$\begin{array}{c}\text { Combine } \\
\text { harvester }\end{array}$} & \multicolumn{5}{|c|}{ Fuel consumption $\left(B ; 1 \mathrm{~h}^{-1}\right)$} \\
\cline { 2 - 6 } & $\begin{array}{c}\text { Engine } \\
(1400 \mathrm{rpm})\end{array}$ & $\begin{array}{c}\text { Engine } \\
(1965 \mathrm{rpm})\end{array}$ & $\begin{array}{c}\text { For technological gear } \\
\text { rotation }\end{array}$ & $\begin{array}{c}\text { For driving over stubble } \\
\left(5 \mathrm{~km} \mathrm{~h}^{-1}\right)\end{array}$ & $\begin{array}{c}\text { Total } \\
(1965 \mathrm{rpm})\end{array}$ \\
\hline $\mathrm{A}$ & $7.80 \pm 0.68$ & $14.50 \pm 0.21$ & $6.80 \pm 0.29$ & $5.50 \pm 0.28$ & $26.80 \pm 0.58$ \\
\hline $\mathrm{B}$ & $9.94 \pm 0.10$ & $16.60 \pm 0.37$ & $7.80 \pm 0.35$ & $6.70 \pm 0.32$ & $31.10 \pm 0.60$ \\
\hline
\end{tabular}


Similar to the findings of Kehayov et al. (2004), a more precise estimate of the combine harvester's performance effectiveness and its environmental impact was selected, i.e., fuel consumption in liters was determined per ton of threshed oilseed rapeseed in this study. The results of this study indicated that increasing the oilseed rape MOG mass fed to the combine harvester up to $15.6 \mathrm{t} \mathrm{h}^{-1}$ resulted in a reduction in fuel consumption per ton of threshed seeds to $3.33 \mathrm{l} \mathrm{t}^{-1}$ (Figure 4). When the abovementioned MOG mass was fed, the CE emissions reached $40.2 \mathrm{~kg} \mathrm{~h}^{-1}$ and approximately $3 \mathrm{~kg} \mathrm{t}^{-1}$, whereas and $\mathrm{CO}_{2}$ reached $121.3 \mathrm{~kg} \mathrm{~h}^{-1}$ and $9.2 \mathrm{~kg} \mathrm{t}^{-1}$ of threshed rapeseed. When the MOG mass feed rate was further increased, the fuel consumption per ton of threshed seeds reversed this trend and began to increase gradually. It was influenced by the exponential variation in hourly fuel consumption used for

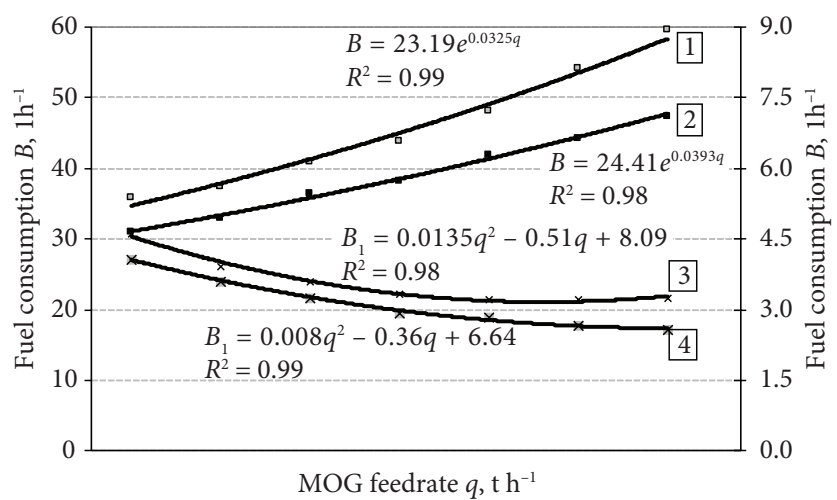

Figure 4. Effect of MOG mass of WOSR Visby fed to combine harvester $\mathrm{B}$ on the hourly fuel consumption $(B)$ and on 1 ton of seed threshing $\left(B_{1}\right)$ when the stubble height $h=0.3 \mathrm{~m}$ and straw chopper rotor $n_{1}=3300 \mathrm{rpm}$. (1) represents hourly fuel consumption when stems are chopped, (2) represents hourly fuel consumption when stems are incorporated in windrows,

(3) represents fuel consumption per ton of threshed seeds when stems are chopped, and (4) represents fuel consumption per ton of threshed seeds when stems are incorporated in windrows

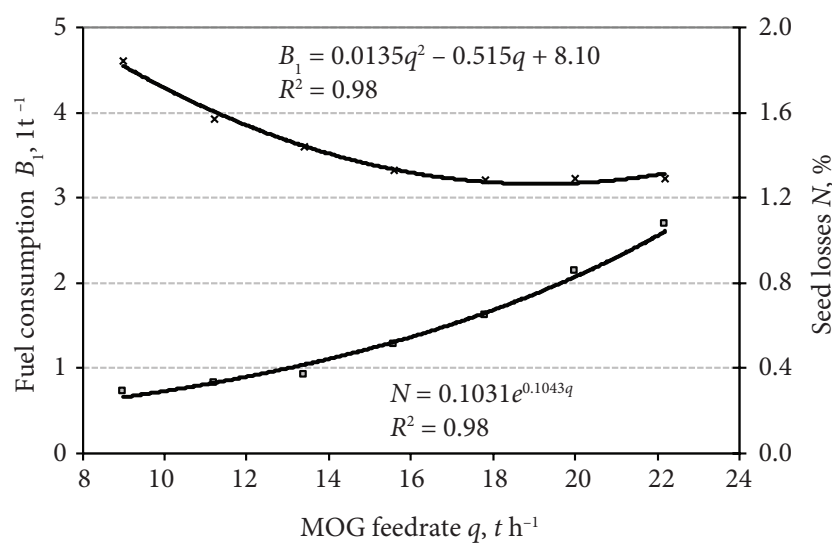

Figure 5. Effect of MOG mass of WOSR fed to combine harvester B on fuel consumption per ton of threshed seeds

$\left(B_{1}\right)$ and on seed losses of straw walker and cleaning shoe $(N)$ when straw was chopped ( $\left.n_{1}=3300 \mathrm{rpm}\right), h=0.3 \mathrm{~m}$, and the grain tank contained $70 \%$ of seeds. (1) represents fuel consumption, (2) represents seed losses driving the combine harvester. If only fuel consumption is assessed, the maximum permissible MOG mass fed to the combine harvester reaches $18 \mathrm{t} \mathrm{h}^{-1}$ because the fuel consumption per ton of threshed seeds has not yet increased. Similar variations in fuel consumption were determined WOSR Visby was harvested using combine harvester A.

When the straw chopper of the combine harvester is switched off, oilseed rape stems are incorporated in windrows. Then, oilseed rape stems are collected using round or rectangular bale presses and rolled into round bales or pressed into square bales. Oilseed rape stems pressed this way are used as biofuel feedstock (Chico-Santamarta et al., 2013). Studies have demonstrated that if $0.2-\mathrm{m}-$ high stubble of WOSR Visby is maintained, the MOG yield reaches $7.35 \mathrm{t} \mathrm{ha}^{-1}$. When the stubble was $0.4 \mathrm{~m}$, the MOG yield reached $4.93 \mathrm{tha}^{-1}$. When the MOG feed rate was increased from 9.0 to $22.2 \mathrm{t} \mathrm{h}^{-1}$ (Figure 4), the average fuel consumption used for chopping increased by $23.7 \mathrm{l} \mathrm{h}^{-1}$, and when it was incorporated in windrows, the increase was $16.4 \mathrm{l} \mathrm{h}^{-1}$. When a reasonable MOG mass feed rate was used $\left(17.8 \mathrm{th}^{-1}\right)$, chopping required $6.21 \mathrm{~h}^{-1}$ more fuel compared to straw incorporation in windrows. When the MOG mass was fed and oilseed rape stems were chopped, $\mathrm{CE}$ emissions reached $44.1 \mathrm{~kg} \mathrm{~h}^{-1}$ and $2.95 \mathrm{~kg} \mathrm{t}^{-1}$ and $\mathrm{CO}_{2}$ reached $133.2 \mathrm{~kg} \mathrm{~h}^{-1}$ and $8.90 \mathrm{~kg} \mathrm{t}^{-1}$ of threshed oilseed rape. When oilseed rape stems were incorporated in windrows, the CE emissions were $~ 12 \%$ lower and amounted to $38.4 \mathrm{~kg} \mathrm{~h}^{-1}$ and $2.60 \mathrm{~kg} \mathrm{t}^{-1}$, whereas $\mathrm{CO}_{2}$ were $116.1 \mathrm{~kg} \mathrm{~h}^{-1}$ and $7.80 \mathrm{~kg} \mathrm{t}^{-1}$.

Apart from using the fuel for technological processes of oilseed rape, e.g., cutting and threshing, the combine harvester's engine uses fuel when turning around at each end of the field, when driving from one field to another, when unloading seeds from the grain tank, and during mechanical inspections. In 2015, operation of the more efficient combine harvester B was observed for 6 days of harvesting WOSR, and $348.7 \mathrm{t}$ of seeds were threshed. The average fuel consumption per ton of threshed seeds was $3.131 \mathrm{t}^{-1} \pm 0.501 \mathrm{t} \mathrm{t}^{-1}$. The fuel consumption of combine harvester A per ton of threshed seeds of WOSR Visby reached $2.88 \mathrm{lt}^{-1} \pm 0.47 \mathrm{l} \mathrm{t}^{-1}$. The effect of oilseed rape variety on the combine harvester's fuel consumption has not been investigated with certainty.

\subsection{Relation between fuel consumption and seed losses from the straw walker and cleaning shoe}

Multi-annual studies have reported that increasing cereals flow through the combine harvester increases seed losses caused due to straw separation and chaff cleaning (A. Feiffer, P. Feiffer, Kutschenreiter, \& Rademacher, 2005; Miu, 2015). The operating speed of the combine harvester is restricted by the permissible limit of seed losses in straw separation and chaff cleaning, which is equal to $0.5 \%$. In adverse conditions, the permissible limit of seed losses is increased to $1 \%$ (Feiffer et al., 2005).

Considering both fuel consumption and seed losses, during harvest of WOSR Visby with combine harvester B, 
the permitted MOG mass reached $15.6 \mathrm{t} \mathrm{h}^{-1}$ (Figure 5), not $17.8 \mathrm{t} \mathrm{h}^{-1}$, because seed losses did not exceed the permissible limit of $0.5 \%$. Under these conditions, the fuel consumption per ton of threshed seeds was $3.331 \mathrm{t}^{-1}$. In severe weather conditions, approximately $30 \%$ more MOG mass may be fed to the combine harvester because the permissible limit of seed losses is increased to $1 \%$ and the fuel consumption per ton of threshed seeds would reach $3.24 \mathrm{lt}^{-1}$, CE emissions would be $2.96 \mathrm{~kg} \mathrm{t}^{-1}$, and $\mathrm{CO}_{2}$ would be $8.96 \mathrm{~kg} \mathrm{t}^{-1}$.

On comparing the results of the present study these studies with those of previous research on combine harvesters that were fed the MOG mass of oilseed rape with seeds equal to 8.68 and $12.60 \mathrm{~kg} \mathrm{~s}^{-1}$, diesel fuel consumption was found to be 15.9 and $16.41 \mathrm{ha}^{-1}$, respectively (Fríd et al., 2017). Having estimated the rape seed yield (3.13 $\mathrm{t} \mathrm{ha}^{-1}$; Fríd et al., 2017), the diesel fuel consumption was estimated to be 5.01 and $5.24 \mathrm{~kg} \mathrm{t}^{-1}$, CE emissions were 4.58 and $4.79 \mathrm{~kg} \mathrm{t}^{-1}$, and $\mathrm{CO}_{2}$ emissions were 13.18 and $13.78 \mathrm{~kg} \mathrm{t}^{-1}$, respectively. The abovementioned studies have estimated slightly higher fuel consumption because their combine harvesters for oilseed rape harvesting had more powerful engines.

The results of this study indicated that the reasonable MOG mass fed to the combine harvester was achieved when the fuel consumption per ton of threshed seeds was the lowest and that the seed losses of straw separation and chaff cleaning did not exceed the permissible limit (Figure 5). More generally, the results also revealed that the permissible MOG mass of oilseed rape fed to the combine harvester depended on the combine harvester's throughput, biometric indices of oilseed rape, stubble height, fuel consumption per ton of threshed seeds, and permissible limit of seed losses associated with the operation of the straw walker and cleaning shoe. When harvesting oilseed rape without using the full width of the combine harvester's cutter or changing the stubble height (using the combine harvester's cutter), the harvester's speed should be adjusted to maintain a reasonable MOG mass feed rate. Moreover, when the operating conditions change, the automatic control system of the technological process of the combine harvester must modify the driving speed in addition to the technological parameters of the threshing apparatus, straw separators, and cleaning shoe so that seed losses do not exceed the permissible limit. Thus, when improving the automatic control system of the combine harvester's forward speed, the latter must be linked to the MOG mass feed rate, permissible limit of seed losses caused due to the operations of the straw walker and cleaning shoe, and fuel consumption per ton of threshed seeds, which serves as the environment pollution indicator.

\section{Conclusions}

1. Studies have shown that the mass of oilseed rape stubble with a height of $0.2 \mathrm{~m}$ and a moisture content of $82.3 \pm 0.7 \%$ comprised $39.2 \pm 2.6 \%$ of the total MOG mass.
It was also estimated that the combine harvester would be fed $11.9 \pm 0.8$ percentage points less MOG mass with a 1.5 percentage points lower moisture content if the stubble height was increased from 0.2 to $0.3 \mathrm{~m}$ during harvest time (i.e., only approximately $50 \%$ of the total mass of the plant stems would be fed to the threshing apparatus of the combine harvester).

2. Studies have confirmed the hypothesis that leaving higher WOSR stubble is a reasonable way to reduce fuel consumption and the emission of air pollutants. When the combine harvester was driven at a speed of $4 \mathrm{~km} \mathrm{~h}^{-1}$, increasing the stubble height of WOSR from 0.2 to $0.4 \mathrm{~m}$, the MOG mass fed to the combine harvester was $7 \mathrm{th}^{-1}$ lower, resulting in hourly fuel consumption reduction of $6.2 \mathrm{l} \mathrm{h}^{-1}$ or $5.7 \mathrm{~kg} \mathrm{~h}^{-1}$ for CE and $16.3 \mathrm{~kg} \mathrm{~h}^{-1}$ for $\mathrm{CO}_{2}$.

3. Furthermore, studies have shown that hourly fuel consumption and the costs associated with harvesting a hectare of oilseed rape only partly reflect the combine harvester performance effectiveness and environmental impact. A more accurate estimate of the combine harvester's performance is the fuel consumption per threshing 1 ton of seeds. Our findings revealed that when the mass of oilseed rape MOG fed to the combine harvester was increased to a reasonable value of $15.6 \mathrm{t} \mathrm{h}^{-1}$ and when seed losses of the straw walker and cleaning shoe did not exceed the permissible limit of $0.5 \%$, the fuel consumption per threshing 1 ton of seeds decreased and reached $3.33 \mathrm{l} \mathrm{t}^{-1}$. Next, CE emissions reached $40.2 \mathrm{~kg} \mathrm{~h}^{-1}$ or approximately $3 \mathrm{~kg} \mathrm{t}^{-1}$ and $\mathrm{CO}_{2}$ emissions reached $121.3 \mathrm{~kg} \mathrm{~h}^{-1}$ or $9.2 \mathrm{~kg} \mathrm{t}^{-1}$ of threshed rapeseed.

4. According to the results of these investigations, it can be stated that when improving the automatic control system of the combine harvester's driving speed, the latter must be linked not only to the MOG mass fed to the combine harvester and the permissible limit of seed losses of straw walker and cleaning shoe but also to fuel consumption per ton of threshed seeds (i.e., the environment pollution indicator).

\section{Acknowledgements}

The authors would like to thank Enago (www.enago.com) for the English language review.

\section{References}

ASAE. (1993). Moisture measurement - forages (No. S358.2). Michigan: ASAE.

Assefa, Y., Prasad, P. V., Foster, C., Wright, Y., Young, S., Bradley, P., Stamm, M., \& Ciampitti, I. A. (2018). Major management factors determining spring and winter canola yield in North America. Crop Science, 58(1), 1-16. https://doi.org/10.2135/cropsci2017.02.0079

Bauša, L., Steponavičius, D., Jotautienè, E., Kemzūraite, A., \& Zaleckas, E. (2018). Application of oilseed rape pod sealants to reduce adverse environmental impacts. Journal of the Science of Food and Agriculture, 98(6), 2428-2436.

https://doi.org/10.1002/jsfa.8735 
Bennett, E. J., Jeremy, A. R., \& Wagstaff, C. (2011). The role of the pod in seed development: strategies for manipulating yield. Tansley Review. New Phytologist, 190(4), 838-853. https://doi.org/10.1111/j.1469-8137.2011.03714.x

Chico-Santamarta, L., Godwin, R. J., Chaney, K., White, D. R., \& Humphries, A. C. (2013). On-farm storage of baled and pelletized canola (Brassica napus L.) straw: Variations in the combustion related properties. Energy, 50, 429-437. https://doi.org/10.1016/j.energy.2012.11.026

Christen, O., \& Friedt, W. (2011). Winterraps (2 Aufl.). Frankfurt am Main: DLG-Verlag.

Dyer, J. A., \& Desjardins, R. L. (2003). Simulated farm fieldwork, energy consumption and related greenhouse gas emissions in Canada. Biosystems Engineering, 85(4), 503-513. https://doi.org/10.1016/S1537-5110(03)00072-2

Feiffer, A., Feiffer, P., Kutschenreiter, W., \& Rademacher, T. (2005). Cereals harvest - clean, safe, fast. Frankfurt: DLGVerlag.

Fríd, M., Dolan, A., Celjak, I., Filip, M., \& Bartos, P. (2017). Harvest of cereals and oilseeds rape by combine harvesters New Holland CX 8090 and New Holland CR 9080. Poljoprivredna Tehnika, 42(2), 19-24.

Gulden, R. H., Shirtliffe, S. J., \& Thomas, A. G. (2003). Harvest losses of canola (Brassica napus) cause large seedbank inputs. Weed Science, 51(1), 83-86. https://doi.org/10.1614/00431745(2003)051(0083:HLOCBN)2.0.CO;2

Haile, T. A., Holzapfel, C. B., \& Shirtliffe, S. J. (2014). Canola genotypes and harvest methods affect seedbank addition. Agronomy Journal, 106(1), 236-242. https://doi:10.2134/agronj2013.0376

Hobson, R. N., \& Bruce, D. M. (2002). Seed loss when cutting a standing crop of oilseed rape with two types of combine harvester header. Biosystems Engineering, 81(3), 281-286. https://doi.org/10.1006/bioe.2001.0011

Jensen, L. S., Mueller, T., Magid, J., \& Nielsen, N. E. (1997). Temporal variation of $\mathrm{C}$ and $\mathrm{N}$ mineralization, microbial biomass and extractable organic pools in soil after oilseed rape straw incorporation in the field. Soil Biology and Biochemistry, 29(7), 1043-1055.

https://doi.org/10.1016/S0038-0717(97)00014-X

Jeong, H. S., Kim, H. Y., Ahn, S. H., Oh, S. C., Yang, I., \& Choi, I. G. (2014). Optimization of enzymatic hydrolysis conditions for extraction of pectin from oilseed rapeseed cake (Brassica napus L.) using commercial enzymes. Food Chemistry, 157, 332-338.

https://doi.org/10.1016/j.foodchem.2014.02.040

Juostas, A., \& Janulevičius, A. (2014). Tractor's engine efficiency and exhaust emissions' research in drilling work. Journal of Environmental Engineering and Landscape Management, 22(2), 141-150. https://doi.org/10.3846/16486897.2013.852556

Kehayov, D., Vezirov, C., \& Atanasov, A. (2004). Some technical aspects of cut height in wheat harvest. Agronomy Research, 2(2), 181-186.

Koga, N., Tsuruta, H., Tsuji, H., \& Nakano, H. (2003). Fuel consumption-derived $\mathrm{CO}_{2}$ emissions under conventional and reduced tillage cropping systems in northern Japan. Agriculture, Ecosystems \& Environment, 99(1-3), 213-219. https://doi.org/10.1016/S0167-8809(03)00132-4

Kosteckas, R., Liakas, V., Šiuliauskas, A., Rauckis, V., Liakienė, E., \& Jakienè, E. (2009). Effect of Pinolen on winter oilseed rape seed losses in relation to maturity. Agronomy Research, 7(1), 347-354.
Lal, R. (2004). Carbon emission from farm operations. Environment International, 30(7), 981-990.

https://doi.org/10.1016/j.envint.2004.03.005

Lutman, P. J. W., Freeman, S. E., \& Pekrun, C. (2003). The longterm persistence of seeds of oilseed rape (Brassica napus) in arable fields. The Journal of Agricultural Science, 141(2), 231240. https://doi.org/10.1017/S0021859603003575

Miu, P. I. (2015). Cereal threshing and separating processes: threshing units. In P. Miu (Ed.), Theory, modelling, and design (pp. 189-260). CRC Press.

https://doi.org/10.1201/b18852-6

Olivier, J. G. J., Maenhout, G. J., \& Peters, J. A. H. W. (2012). Trends in global $\mathrm{CO}_{2}$ emissions-2012 (Report). Netherlands Environmental Assessment Agency, Hague.

Oyediran, O. B., \& Wufem, B. M. (2017). Models for computing emission of carbon dioxide from liquid fuel in Nigeria. American Journal of Mathematical and Computer Modelling, 2(1), 29-38.

Pari, L., Assirelli, A., Suardi, A., Civitarese, V., Del Giudice, A., Costa, C., \& Santangelo, E. (2012). The harvest of oilseed rape (Brassica napus L.): The effective yield losses at on-farm scale in the Italian area. Biomass and Bioenergy, 46, 453-458. https://doi.org/10.1016/j.biombioe.2012.07.014

Peltonen-Sainio, P., Pahkala, K., Mikkola, H., \& Jauhiainen, L. (2014). Seed loss and volunteer seedling establishment of oilseed rapeseed in the northernmost European conditions. Agricultural and Food Science, 23, 327-339.

https://doi.org/10.23986/afsci.41530

Price, J. S., Hobson, R. N., Neale, M. A., \& Bruce, D. M. (1996). Seed losses in commercial harvesting of oilseed rape. Journal of Agricultural Engineering Research, 65(3), 183-191. https://doi.org/10.1006/jaer.1996.0091

Rathke, G. W., Behrens, T., \& Diepenbrock, W. (2006). Integrated nitrogen management strategies to improve seed yield, oil content and nitrogen efficiency of winter oilseed rape (Brassica napus L.): a review. Agriculture, Ecosystems \& Environment, 117(2-3), 80-108.

https://doi.org/10.1016/j.agee.2006.04.006

Reckleben, Y., \& Vosshenrich, H.-H. (2008). Cereals harvest by the high cut. Getreide, 13(2), 108-109.

Reşitoğlu, İ. A., Altinişik, K., \& Keskin, A. (2015). The pollutant emissions from diesel-engine vehicles and exhaust aftertreatment systems. Clean Technologies and Environmental Policy, 17(1), 15-27. https://doi.org/10.1007/s10098-014-0793-9

Špokas, L., \& Steponavičius, D. (2011). Fuel consumption during cereal and oilseed rape harvesting and methods of its reduction. Journal of Food, Agriculture \& Environment, 9(3/4, part 1), 257-263.

Špokas, L., Velička, R., Marcinkevičienè, A., \& Domeika, R. (2004). Optimization of spring oilseed rape harvest time by choosing crop varieties. Die Bodenkultur, 55(3), 113-120.

Strakšas, A., Kučinskas, V., Šniauka, P., \& Vaiciukevičius, E. (2013). Singularities of white clover seed harvesting in Lithuania. Agricultural Engineering, 45(1), 96-110.

Teper, D., Skubida, P., Semkiw, P., \& Skowronek, W. (2013). Exploitation of oilseed rape flow by bee colonies in stationary and migratory apiary. Journal of Apicultural Science, 57(1), 85-94. https://doi.org/10.2478/jas-2013-0010

Thiyam, U., Kuhlmann, A., Stöckmann, H., \& Schwarz, K. (2004). Prospects of oilseed rapeseed oil by-products with respect to antioxidative potential. Comptes Rendus Chimie, 7(6-7), 611616. https://doi.org/10.1016/j.crci.2004.02.011 
Tomita, M., Kawase, Y., Takahashi, H., Shimizu, K., Chiba, M., Harano, M., Sugiura, Y., \& Seki, E. (2013). Development of a torque measurement device for a head-feeding combine harvester engine output shaft. Japan Agricultural Research Quarterly: JARQ, 47(3), 243-248.

https://doi.org/10.6090/jarq.47.243

United States Department of Agriculture. (2018). World agricultural production. Retrieved from https://apps.fas.usda.gov/ psdonline/circulars/production.pdf

West, T. O., \& Marland, G. (2002). A synthesis of carbon sequestration, carbon emissions, and net carbon flux in agriculture: comparing tillage practices in the United States. Agriculture, Ecosystems \& Environment, 91(1-3), 217-232. https://doi.org/10.1016/S0167-8809(01)00233-X

Zając, T., Klimek-Kopyra, A., Oleksy, A., Lorenc-Kozik, A., \& Ratajczak, K. (2016). Analysis of yield and plant traits of oilseed rape (Brassica napus L.) cultivated in temperate region in light of the possibilities of sowing in arid areas. Acta Agrobotanica, 69(4), 1-13.

https://doi.org/10.5586/aa.1696 